\title{
CAVES AND KARST-LIKE FEATURES IN PROTEROZOIC GNEISS AND CAMBRIAN GRANITE, SOUTHERN AND CENTRAL SRI LANKA: AN INTRODUCTION
}

\author{
JAME IN DRUGE PSEVDOKRAŠKE OBLIKE V PROTEROZOJSKEM \\ GNAJSU IN KAMBRIJSKEM GRANITU JUŽNE IN CENTRALNE \\ ŠRI LANKE: UVOD
}

\author{
R. Armstrong L. OSBORNE ${ }^{1,5}$, Wasantha S. WELIANGE 2 , Pathmakumara JAYASINGHA ${ }^{3}$, A.S. DANDENIYA ${ }^{4}$, \\ A.K. Prageeth P. ALGIRIYA ${ }^{2} \&$ Ross E. POGSON ${ }^{5}$
}

\begin{abstract}
UDC 551.435.8(548.7)

R. Armstrong L. Osborne, Wasantha S. Weliange, Pathmakumara Jayasingha, A.S. Dandeniya, A.K. Prageeth P. Algiriya \& Ross E. Pogson: Caves and karst-like features in Proterozoic gneiss and Cambrian granite, southern and central Sri Lanka: An introduction.

There has been little study of the geology and geomorphology of the caves and karst-like features developed in the Proterozoic gneiss and Cambrian granite of Sri Lanka. This lack of study is surprising given that caves and rockshelters in these rocks contain significant archaeological and cultural sites. Caves and karren, both mimicking those developed in carbonate rocks, have formed both in gneiss, which is the dominant rock type of the Proterozoic crust of the island and in granite. In addition to overhangs, boulder caves, soil pipes and tectonic caves, tunnel caves, arch caves and block breakdown caves of significant size are developed in siliceous rocks in Sri Lanka. While metamorphosed dolomites are interfoliated within the gneissic suite, simple removal of carbonate by solution from within the surrounding rock cannot account for all or most of the speleogenesis observed. While spalling and breakdown are responsible for cave enlargement, cave initiation is probably due to either phreatic solution of silicates and/or phantom rock processes. Speleothems and cave minerals including silicates, phosphates, gypsum, carbonates and niter are found in the caves. Active silicate speleothems are not restricted to joints and fissures and suggest that solution of silicates is currently occurring within the body of the rock in the vadose zone. While guano is the likely source of the phosphate, sulfate and nitrate, the source of the calcium in the carbonates remains unclear. Caves in the intrusive and metamorphic rocks of Sri Lanka are enigmatic. They are unexpectedly similar in appearance to their carbonate karst counterparts. Continuing research will allow them to hold a mirror to our understanding of speleogenesis, mineralization and sedimentation in carbonate karst caves.
\end{abstract}

Izvleček

UDK 551.435.8(548.7)

R. Armstrong L. Osborne, Wasantha S. Weliange, Pathmakumara Jayasingha, A.S. Dandeniya, A.K. Prageeth P. Algiriya \& Ross E. Pogson: Gnajsu in Kambrijskem granitu južne in centralne Šri Lanke: Uvod

Kljub temu, da so spodmoli v proterozoiskem in kambrijskem granitu Šri Lanke pomembna arheološka najdišča, je bilo o njih objavljenih le malo raziskav. Jame in škraplje, podobne tistim v karbonatnih kamninah, so razvite $\mathrm{v}$ gnajsu, ki je dominantna kamnina proterozoiske skorje otoka in v granitu. V silikatih Šri Lanke najdemo različne oblike jam: previse, spodmole, jam med balvani, tektonske jame, jame $\mathrm{v}$ podorih, naravne mostove in tunelske jame. Speleogenezo bi težko razložili zgolj z raztapljanjem vključkov metamorfiziranega dolomita v gnajsu. Luščenje in podiranje sta verjetno ključna $v$ fazi kasnejše rasti jam, začetni razvoj pa je verjetno povezan z raztapljanjem silikatov $\mathrm{v}$ freatični coni in/ali fantonskimi procesi. V jamah najdemo različne tipe sig in jamskih mineralov, med njimi silikate, fosfate, sadro, carbonate in soliter. Izločanje silikatnih sig ni omejeno le na razpoke, kar nakazuje recentno raztapljanje silikatne matrice v vadozni coni. Gvano vir fosfatov, sulfatov in nitratov, vir kalcija pa zaenkrat ostaja neznanka. Jame v intruzijah in metamorfnih kamninah Šri Lanke so skrivnostne. So presenetljivo podobne jamam v karbonatnem krasu. Njihovo raziskovanje bo morda omogočilo tudi boljše razumevanje speleogeneze in sedimentov $\mathrm{v}$ karbonatnih jamah.

${ }^{1,5}$ Corresponding author, Education \& Social Work, A35, The University of Sydney, NSW, 2006, Australia, armstrong.osborne@sydney.edu.au

${ }^{2}$ Postgraduate Institute of Archaeology, Bauddhaloka Mawatha, Colombo 7, Sri Lanka.

${ }^{3}$ Research Laboratory, Central Cultural Fund, Independence Avenue, Colombo 07, Sri Lanka

${ }^{4}$ BGJF Consultancy Services, 35A 1/2, Sunethradewi Road, Kohuwala, Nugegoda, Sri Lanka.

${ }^{5}$ Australian Museum, 6 College Street, Sydney, NSW, 2010, Australia.

Received/Prejeto: 4.6 .2012 


\section{INTRODUCTION}

Sri Lanka is a continental island with an area of approximately $65,610 \mathrm{~km}^{2}$ located off the southeastern tip of the Indian subcontinent. Intensely folded and highly metamorphosed Proterozoic rocks underlie ninety percent of the island (Cooray, 1994), representing the interlocking of three crustal units during the formation of the Gondwana supercontinent (Mathavan et al., 1999). The Proterozoic sequence is in places intruded by Cambrian granites (Fernando \& Iizumi, 2001). Miocene limestone outcrops as a fringe along the northwestern corner of the island (Fig. 1).
A great range of cave types, karst and karst-like features occur in Sri Lanka in a range of host rocks. "Lena" is a Singhalese word for "cave" and is used here instead of cave where it is part of a well-established place name. The Miocene limestone is a major karst aquifer (Villholth \& Rajasooriyar, 2010) and Gebauer (2010) reported caves in it. Few caves and other karst features in the Miocene limestone have been described in the literature, but there are confirmed reports of both caves and cenote-like features.

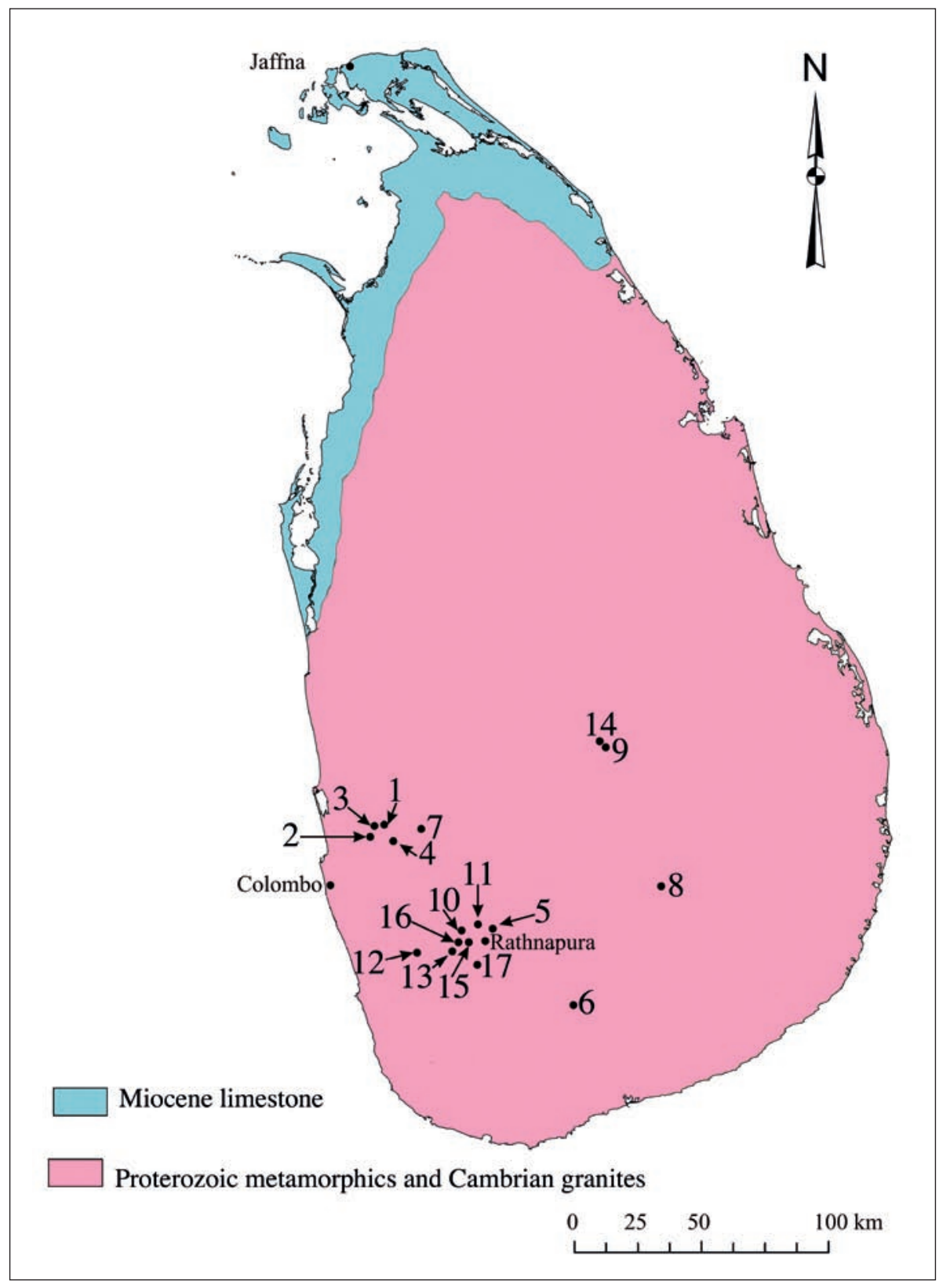

Fig. 1: Sri Lanka Map

1, Varana Rajamaha Viharaya; 2, Pilikuththuwa Rajamaha Viharaya rock temple site; 3, Koskandawala Rajamaha Viharaya rock temple site; 4, Maligathenna rock temple site; 5, Ma Lena dolomite cave; 6, Vavulpane tufa cave; 7, Alavala Pothgul Lena; 8, Ravana Ella Cave; 9, Lunugala Lena Nitre Cave; 10, Batathota Cave \& Sthreepura Cave; 11, Batadomba Lena; 12, Fa-Hien Lena; 13, Kosgala Vavul Lena; 14, Ravana Cave, Oil Lamp Cave \& Twin Cave; 15, Pelpola Cave; 16, Karannagoda Rajamaha Viharaya; 17, Kukuluwa Kanda Rajamaha Viharaya. 
Metamorphosed dolomites and calcsilicate rocks occur within the Proterozoic metamorphic sequence and small, impounded karsts with karst caves (e.g. at Ma Lena) are developed in the dolomites. Springs with carbonate-rich water rising from the metamorphic sequence have deposited tufa mounds. Caves with well-developed carbonate speleothems such as Vavulpane Calcareous Cave have formed in these mounds. Small caves have been observed, but not investigated, in ironstones near Doowa. There are also unconfirmed reports of caves in small deposits of dune limestone along the eastern coastline of Sri Lanka.

Rock shelters and more complex caves in Proterozoic gneiss and Cambrian granite are the location of most of the important prehistoric and historic archaeological sites and temples in Sri Lanka such as Batadomba Lena (see Kennedy \& Deraniyagala, 1989).

While there has been some discussion of palaeokarst (Dahanayake \& Subasinghe, 1989; Mathavan, Kalubandara \& Fernando, 2000) and geotechnical problems attributed to karst (Laksiri, Gunathilake \& Iwao, 2005) there is very little literature about the caves and karst of Sri Lanka except in relation to archaeological and historical sites.

Although caves feature in Sri Lankan ancient literature and folktales, little has been written scientifically about caves since Davey (1821) described temple caves and niter-bearing caves. Peet $(1945,1946)$ described Nitre Cave following expeditions in 1945 and published one of the very few maps of a Sri Lankan cave surveyed in the $20^{\text {th }}$ century.

Kukla (1958) gave a general introduction to the caves of Sri Lanka, focusing on features in the Miocene limestone in the Jaffna Peninsula and included a plan of the tidal well at Puttur. He briefly mentions caves in crystalline rocks noting that Maturata Cave, filled with hydromagnesite, is the most interesting and that "Stripura Cave in Battatota mountain ... more than 55 metres deep is most probably the biggest one".
Deraniyagala (1965) introduced the caves of Sri Lanka to the international cave research community, noted that over one hundred caves required investigation and preservation and asked for international assistance. Siffre (1975) gave a dramatic account of his adventures in Sri Lankan caves including many of the caves described here. Brooks (1995) reported on a brief visit to caves in Sri Lanka including Batadomba Lena and Sthreepura Cave and commented that the development of caves in gneiss was unusual. Brooks (1995, Ms 20) gave a recognisable description of Sthreepura Cave ("Batatota Subterranean Cavern").

Gebauer et al. (1996) presented a background to and a detailed bibliography of the caves in Sri Lanka. This was expanded and refined by Gebauer (2010). Gebauer's work, which includes 310 entries for caves and "cave-like objects" in Sri Lanka, has proved to be a vital source for obscure references regarding Sri Lankan caves. Of the 310 "caves" recorded in Sri Lanka, Gebauer (2010) reported being aware of only seven caves that had been mapped.

Jayasingha et al. (2009) described the sedimentary sequence in a small rock shelter at Varana Rajamaha Viharaya, while Jayasingha et al. (2010) described some of the different types of caves found in Sri Lanka.

This is the first major publication from the project "Cave Science Sri Lanka", which began in 2008 with the aim of establishing cave science research and developing a course in cave science at the Postgraduate Institute of Archaeology, University of Kelaniya. The main focus of this paper and of the project "Cave Science Sri Lanka" is on caves and karst-like forms developed in the highgrade metamorphic rocks of the Proterozoic sequence and in plutons intruding them. Since 2008, forty-seven caves have been investigated. Thirty-six of these caves have been mapped by the Sri Lankan members of the project, twenty-four have been investigated in more detail and samples have been collected from eleven caves for analysis.

\section{DISTRIBUTION OF GNEISS/GRANITE CAVES AND RELATED FEATURES}

While some caves in gneisses and granites occur in isolation, many occur in clusters and are often associated with a suite of surface features including inselbergs, tors, whalebacks, grikes, runnels, flutes, pans (kaminetza), subsoil weathering forms and tufa deposits. In areas of low relief gneiss caves generally occur in and around the base of prominent inselbergs (e.g. Varana Rajamaha Viharaya, Sigiriya), while in areas of high relief they tend to occur grouped together in hill sides or at the base of long cliff lines which elsewhere lack caves (e.g. Batathota Cave, Sthreepura Cave and Two-Crack Cave). The influence of specific rock types on cave and surface feature development has not been investigated at this stage of the project. 


\section{KARST-LIKE SURFACE LANDFORMS IN GNEISS AND GRANITE}

Karst-like surface and subsoil solution sculpture occurs where gneiss and granite crops out as inselbergs (Fig. 2A) and in outcrops with significant exposed surfaces, such as whalebacks (Fig. 2B).

\section{RUNNELS}

What appear from a distance to be giant rillenkarren are developed in the surface of some prominent granite outcrops such as at Varana Rajamaha Viharaya (Fig. 2C). On close inspection these features are less like rillenkarren found on limestone and more like the runnels developed in silicic features such as Uluru in central Australia. Runnels in the granite and gneiss tend to have a $U$ rather than $\mathrm{V}$-shaped cross-section, with their floor developed into a series of pans (Fig. 2D). In addition, much smaller runnels form on surfaces with low slopes. Often these are guided by selective weathering of mafic bands/folia in the bedrock.

\section{PANS}

Pans occur in flat and gently sloping surfaces and in the bottoms of runnels (Fig. 2E). Selective weathering of small crystals, leaving behind large quartz crystals is frequently seen in the bottom of small pans (Fig. 2F). Large pans in flat surfaces are often associated with vegetation (Fig. 2G).

\section{FLUTES}

These are indentations in vertical rock surfaces with a semicircular cross-section and largely parallel sides. Flutes often form in groups, guided by poorly expressed vertical parallel joints (Fig. 2H). At Koskandawala it is possible to see that flutes form on tight vertical joints, while more open vertical joints may develop into slots or incipient caves.

\section{POSSIBLE SUBSOIL WEATHERING FORMS}

A range of rounded forms, similar to sub-soil weathering forms developed in limestone karst (see Slabe \& Hong, 2009) is developed around the base of inselbergs and where gneiss or granite crops out as smaller solitary rocks.

At Pilikuththuwa what appear to be sub-soil flutes are developed on the top edge of a large boulder (Fig. 2I), while at Varana Rajamaha Viharaya what looks like a tree hollow is also developed towards the top edge of a similar boulder (Fig. 2J). What appear to be subsoil forms have been observed at several other rock-temple sites, suggesting that the boulders were once surrounded by soil or weathered rock and that some of the boulders may be residual core-stones.

\section{TUFA DEPOSITS}

Deposits of calcareous tufa of varying scale are found associated with springs and seeps rising from the gneiss. The largest deposit seen so far forms a large mound blocking Halwinne Dola, a tributary of the Andoly River. Vavulpane Calcareous Cave is developed in this mound. The mound is still active and is fed from a spring rising along a joint in granitic gneiss not carbonate rock.

Small tufa deposits occur from seeps in the cliffs adjacent to some of the large caves such as Batathota and Batadomba, these are often partly covered with ferns and algae.

\section{GNEISS \& GRANITE CAVE TYPES}

\section{ROCK SHELTERS}

The most abundant cave-like features developed in gneisses of Sri Lanka are rock shelters, also called abris or overhangs. Rock shelters are usually distinguished from true caves by being wider than they are deep and by lacking a dark zone. The Singhalese equivalent of rock shelter is "gal-ge" meaning stone house. Of the 310 entries in his cave registry, Gebauer (2010) identified 33 as rock shelters and 57 as caves. This seems to be proportionally incorrect. However, this is hardly surprising since 181 (58\%) of Gebauer's entries were "unconfirmed cavish objects" and because shelters are so common that most will not be reported.

\section{TECTONIC CAVES}

Tectonic caves have formed by mass movement of separating blocks along cliff-lines developed in gneiss. TwoCrack Cave, located in the cliff just south of Batathota Cave, is a good example of this type of cave.

\section{BOULDER CAVES}

Boulder caves are the spaces between large stacked boulders found in rock falls, block streams and riverbeds. As both gneiss and granite are strong rocks that tend to fail along joints producing large blocks, boulder caves are relatively common in the highland regions of Sri Lanka. 

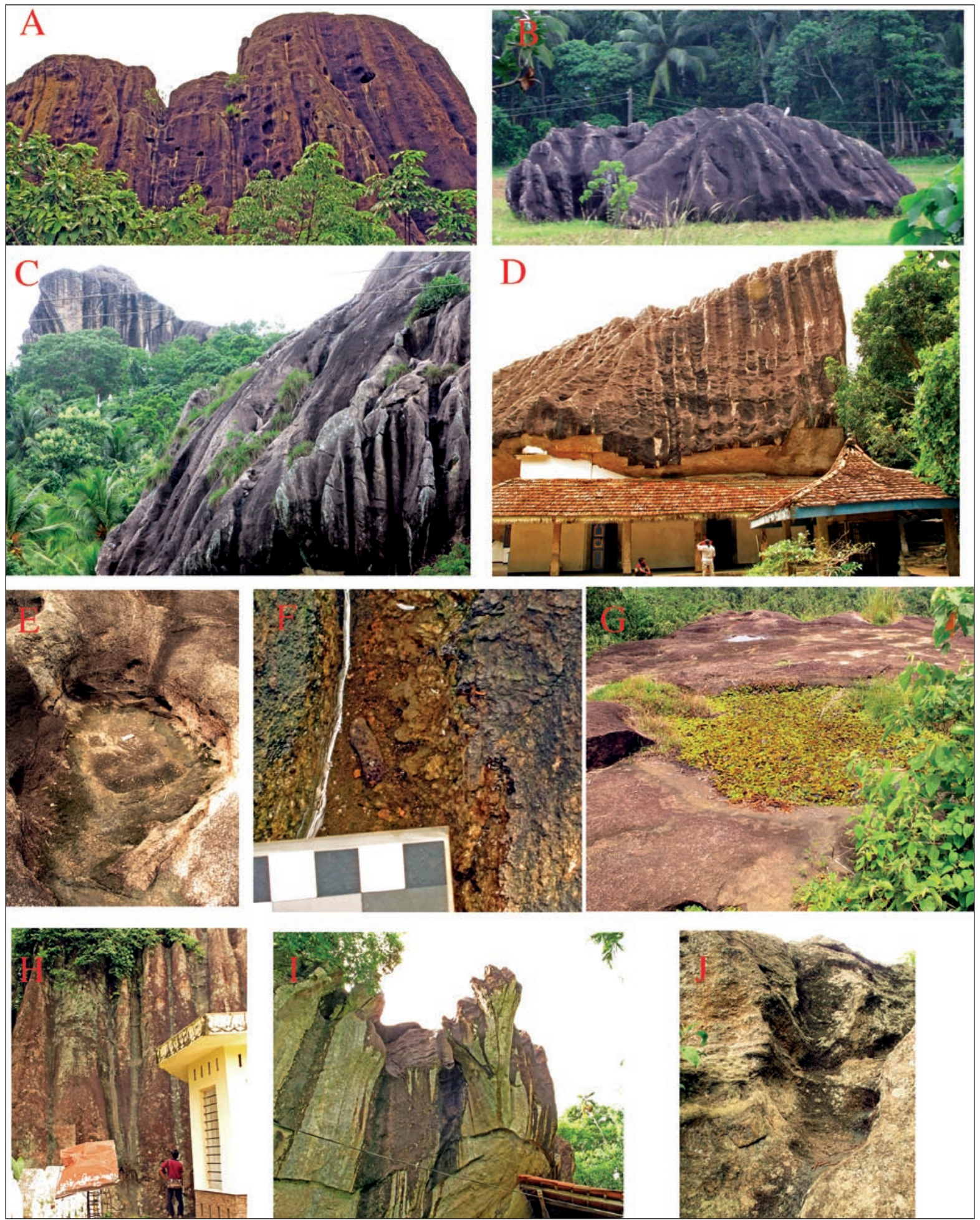

Fig. 2: Surface Features

A, Inselberg, Koskandawala Rajamaha Viharaya rock temple site; B, Whaleback; C, Runnels, Varana Rajamaha Viharaya; D, Runnels with pans in base, Varana Rajamaha Viharaya; E, Pan, Koskandawala Rajamaha Viharaya rock temple site; F, Pan with resistant quartz crystals, Varana Rajamaha Viharaya; $G$, Pan with vegetation, Varana Rajamaha Viharaya; $H$, Flutes developed along vertical joints, Koskandawala Rajamaha Viharaya rock temple site; I, Sub-soil flutes on large isolated rock, Pilikuththuwa Rajamaha Viharaya rock temple site; J, Sub-soil feature Varana Rajamaha Viharaya. 


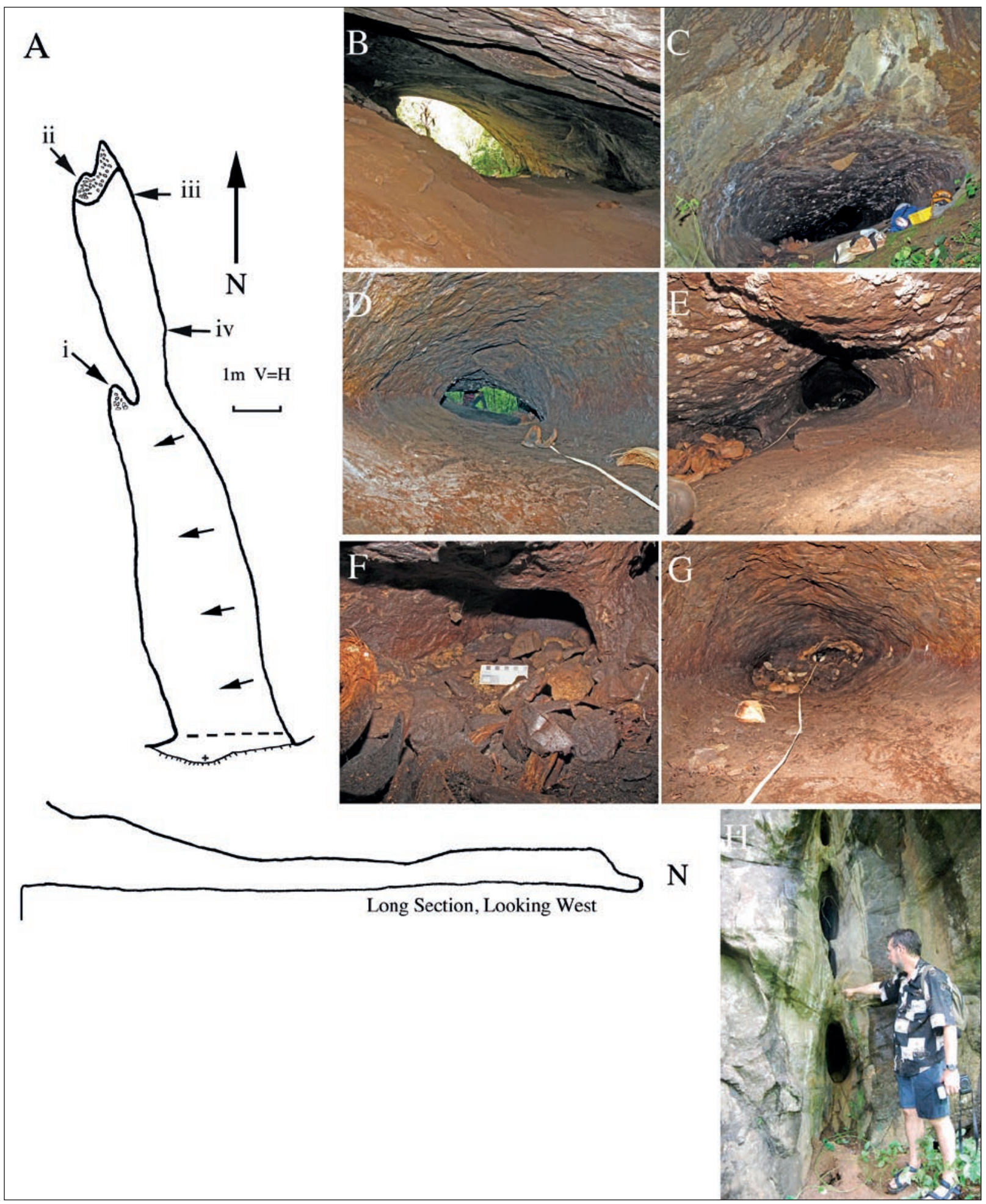

Fig. 3: Tunnel Caves

A, Alavala Tunnel Cave, map and long section; B, Looking out from Ravana Ella Cave, note elliptical profile; C, Alavala Tunnel Cave, looking in; D, Alavala Tunnel Cave, looking out, note slope to right hand side (west); E, Alavala Tunnel Cave, looking in from just south of junction, note lower side passage with angular cobbles and cobbles extending down from main passage; F, Alavala Tunnel Cave, detail of cobble pile in an in front of side passage; G, Looking in towards end of Alavala Tunnel Cave showing pile of cobbles at termination; H, Open Joints with elliptical tubes in cliff west of Alavala Tunnel Cave. 
Very large boulder caves are important components of rock temple sites such as Pilikuththuwa, Maligathenna and Varana. Most of the 80 caves at Pilikuththuwa are boulder caves, while at Maligathenna a very large boulder cave approximately $30 \mathrm{~m}$ long and $20 \mathrm{~m}$ wide with a ceiling height of up to $2 \mathrm{~m}$ is used as a preaching hall.

\section{TUNNEL CAVES}

Tunnel caves are one of the most abundant types of gneiss caves that are not rock shelters. They are elongate cavities (Fig. 3A) with a distinctive elliptical cross-section (Fig. 3B). This cross-sectional shape is clearly visible in images taken from the cave looking out (Figs 3B \& 3D). Depending on the structural setting, the long axis of the ellipse may be horizontal, vertical or sloping. The principal axis of the elliptical cross-section ranges from 1-2 $\mathrm{m}$ in small examples such as Alavala Tunnel Cave and up to $12 \mathrm{~m}$ in large examples such as Ravana Ella Cave and Lunugala Lena. In appearance tunnel caves resemble phreatic tubes in karst caves.

Small tunnel caves are often formed completely in bedrock and guiding joints that may be apparent in the cliff face near their entrance are often not visible inside the cave. It is unclear if these features begin as true solution tubes or by some other process such as the removal of phantom rock.

Alavala Tunnel Cave, located just downhill from Alavala Pothgul Lena, gives some clues as to how these caves might develop and expand. While it is clear that spalling has and continues to be an important process in the cave, no fragments of exfoliated rock are found on the cave floor, rather the cave floor consists of clean rock with a dark, probably manganiferous coating. Two small piles of rounded bedrock fragments are found in the cave, one close to the termination of the lower passage ("i" in Fig. 3A, Fig. 3F) and the other at the far (northern) end of the cave ("ii" in Fig. 3A, Fig. 3G). These suggest that rather than accumulating in the cave, exfoliated spalls are washed out of the cave, during pluvial events. A mechanism for removing fallen spalls is essential for lateral expansion of tunnel caves.

\section{ARCH CAVES}

A large chamber with a triangular-shaped plan and crosssection is the principal feature of arch caves (Fig. 4). Three arch caves have so far been investigated: Batathota Cave (Divaguhawa Lena in Kuruvita, Fig. 5), Batadomba Lena and Fa-Hien Lena, all in the Rathnapura district. The general shape of these chambers can be seen in views looking in and out. Figs 6A \& 6B show views looking into and out from Batadomba Lena. Figs 6C \& 6D show views looking into and out from Fa-Hien Lena. In Fig. 6C the prominent axial structure is visible at the far end of the chamber, while close to the entrance a smoother, more semicircular profile is developed.

Some arch caves, such as the small cave to the west of Batadomba Lena, are developed along the axis of an antiform in the foliation of the gneiss (Fig. 6F), while the development of Batathota Cave is strongly influenced by joints.

It is unclear if these caves are remnants of larger cavities, which have been truncated by cliff retreat or if they result from tunnels being modified by spalling, which has become more intense closer to the surface. The presence of solution-like features such as pockets and halftubes in the ceilings of Batathota Cave and Batadomba Lena suggests that processes other than breakdown and spalling have a role in the development of arch caves in the gneiss.

Modification of arch caves during their transformation into temples has probably blocked access to their inner sections. The building housing the reclining Buddha at Fa-Hien Lena appears to be constructed on artificial fill, supported by a retaining wall at its rear and blocking a lower-level cave entrance (Fig. 4C). Large numbers of bats enter and exit a narrow gap between the fill and a descending cave wall. This potential lead has yet to be investigated, but the number of bats entering and exiting suggests that a significant volume of cave may occur here.

\section{BLOCK BREAKDOWN CAVES}

Two examples of block breakdown caves have so far been investigated, Sthreepura Cave and Kosgala Vavul Lena, both are located in the Rathnapura District. These are large cavities, which resemble breakdown chambers in karst caves.

Like most of the caves in Sri Lanka recorded by Gebauer (2010), the name and location of Sthreepura Cave is greatly confused in the literature. This is made worse by its close proximity to two other caves, Batathota Cave (arch cave with temple) and Two-Crack Cave (tectonic cave), which seem to have become conflated under the heading "Batatota Lena" in Gebauer (2010, pages 35-37). Most of the descriptions appear to be of Sthreepura Cave rather than the more obvious temple cave (Batathota Cave $=$ Divaguhawa Lena in Kuruvita).

Kukla (1958) suggested that "Stipura Cave" was probably the biggest cave in Sri Lanka, but his text suggests he was referring to Batathota Cave = Divaguhawa Lena in Kuruvita not Sthreepura Cave as he mentions use of the cave as a Buddhist temple. Brooks (1995) gave the best previous description of Sthreepura Cave.

The entrance to Sthreepura Cave is located in the cliff base some $75 \mathrm{~m}$ east of Batathota Cave. Sthreepura Cave extends approximately $80 \mathrm{~m}$ to the north from its 


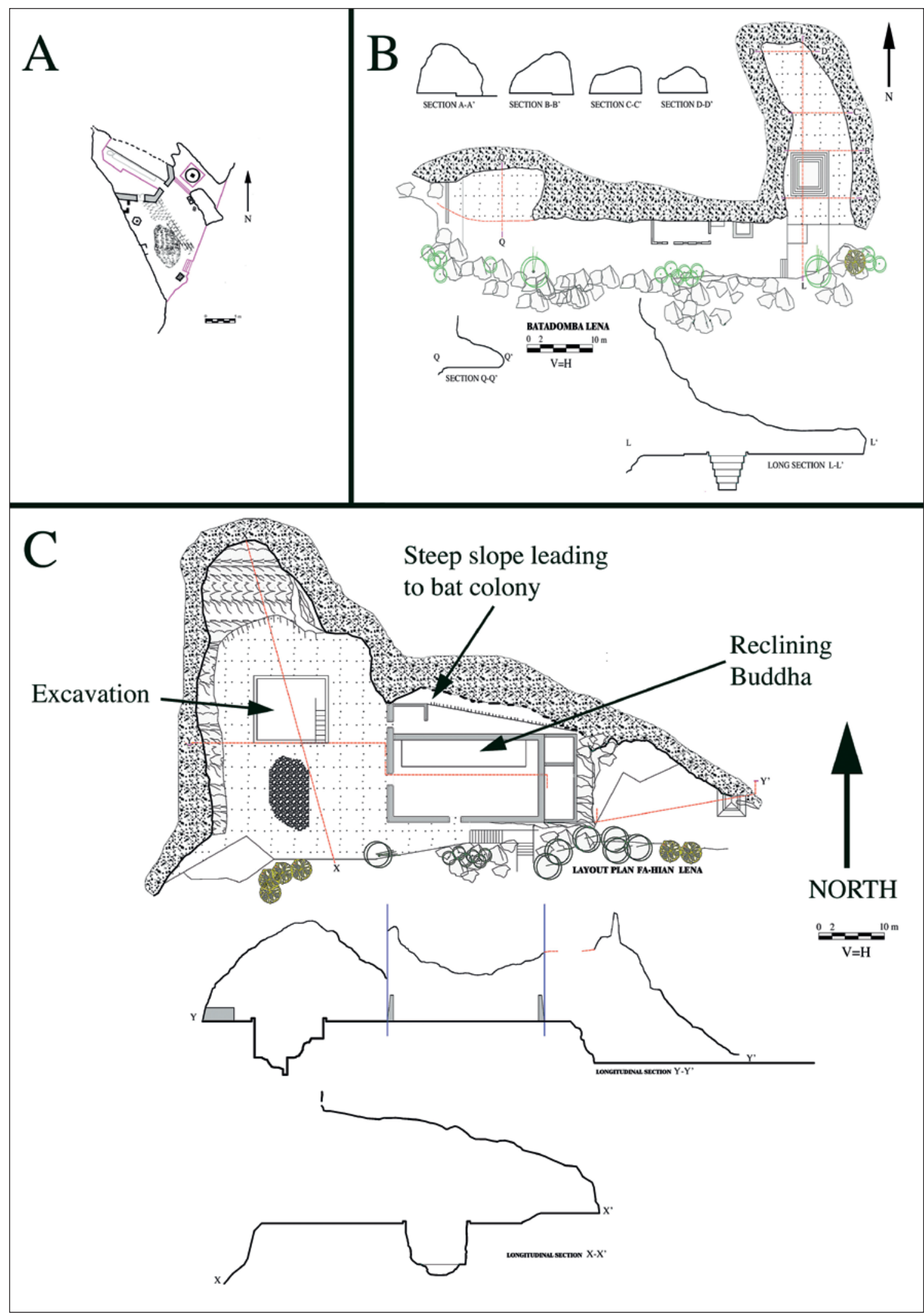

Fig. 4: Arch Cave Maps, all at same scale

A, Batathota Cave- Divaguhawa lena in Kuruvita; B, Batadomba Lena; C, Fa-Hien Lena. 


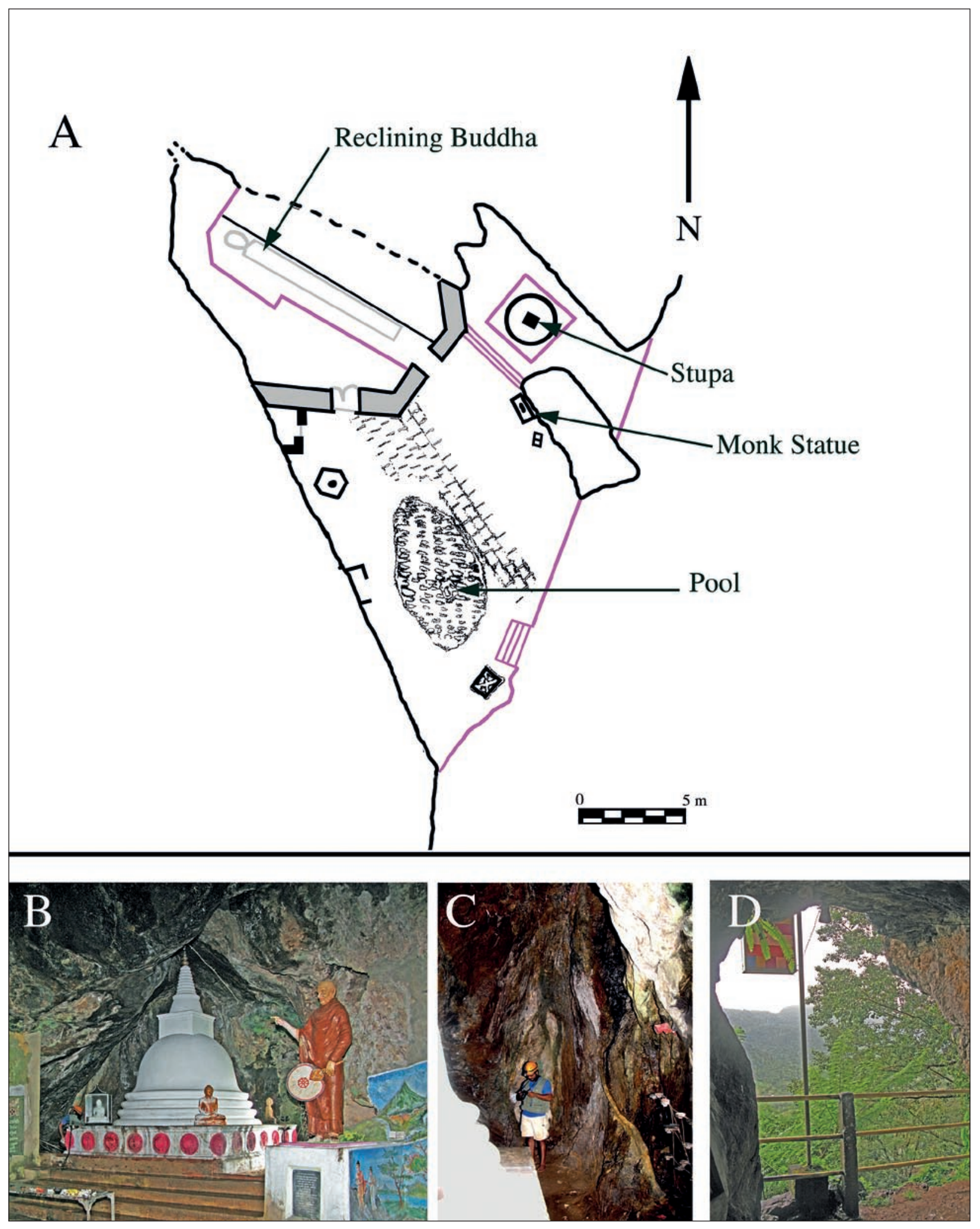

Fig. 5: Batathota Cave- Divaguhawa Lena in Kuruvita

A, Map; B, Looking NE towards stupa; C, Looking NW towards elliptical pocket at end of Stupa Chamber; D, Looking SE from Stupa Chamber, note profile of cave wall. 

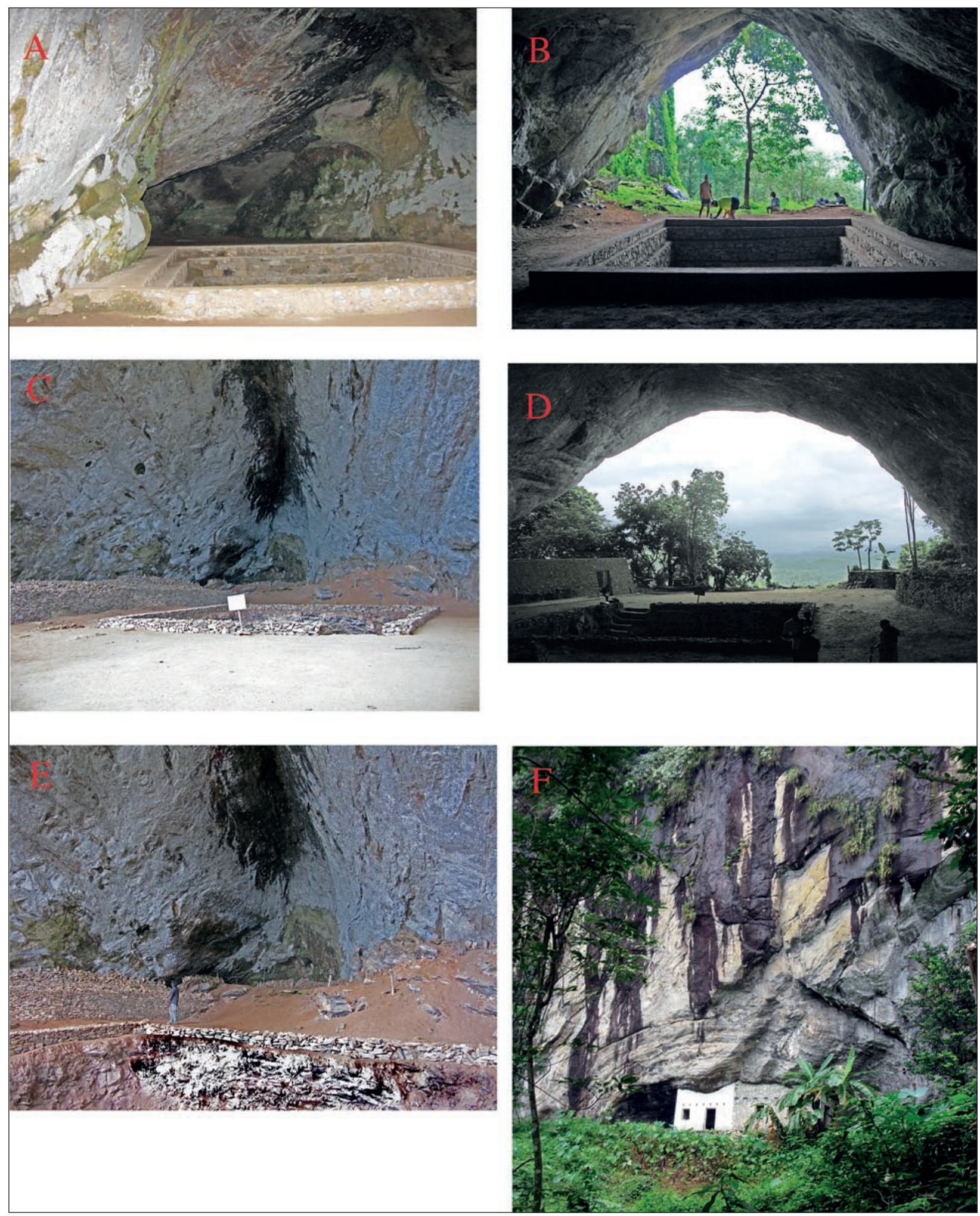

Fig. 6: Arch Caves

A, Batadomba Lena, looking in; B, Batadomba Lena, looking out; C, Fa-Hien Lena, looking in; D, Fa-Hien Lena, looking out; E, FaHien Lena, looking in showing size of cave, note person for scale; F, Hut constructed in small cave guided by antiform, Batadomba Lena. 
entrance and runs perpendicular to the cliff line. The main components of the cave are the Welcome Chamber, Connecting Passage, Guano Chamber, the Passage of Bats, a connecting rift and three small tubes (Fig. 7A).

When inspected in August 2010 a lake extended south from the Guano Chamber and a small tube at the northern end of the cave was blocked by water (Fig. 7B).

Breakdown in the cave can be divided into three distinct zones. In the first zone, consisting of the Welcome Chamber and the Connecting Passage, joints striking NNW-SSE guide breakdown (Fig. 7C). In the second zone, consisting of the Guano Chamber, NE-SW striking joints guide breakdown (Fig. 7D). In the third zone, the Passage of Bats, as in the first zone, NNW-SSE striking joints guide breakdown. The remnant of a small halftube is preserved along the axis of breakdown in the ceiling of the Passage of Bats (Fig. 7E).

Most of the cave is developed in gneiss, including all of the fallen blocks and most of the wall and ceiling. Dolomite is exposed in the lower wall and floor of the cave at the northwest corner of Guano Chamber.

As "Kosgalla Cave, Ratnapura", Kosgala Vavul Lena receives very brief mention in Gebauer (2010). This is due to vague references to the cave in tourist guidebooks. Located high in a hillside now developed as a rubber plantation, the dominant feature of Kosgala Vavul Lena is a large breakdown chamber with an "A" type ceiling, where breakdown has occurred along the intersection of two dipping joints (Fig. 7F). On the northwestern side of the central axis smaller cavities are developed, oriented perpendicular to the main axis of the cave. Unlike Sthreepura Cave, the principal axis of Kosgala Vavul Lena runs parallel, not perpendicular, to the side of the valley in which it is developed.

The main chamber of Kosgala Vavul Lena is asymmetric in cross section, with the chamber on the southeastern side of the central breakdown pile extending deeper than that on the northwestern side. At the deepest point of the cave, at its far southeast corner, a small pool of water fills a northeast trending passage. A white carbonate rock is exposed in the northwestern wall and in tubes at the lowest part of the cave. While the carbonate rock is preferentially removed relative to the surrounding gneiss, the field relationships do not suggest that the cave here is simply the result of solution of carbonate from within surrounding gneiss.

Remnants of half tubes and anastomoses are visible at the entrance, in the ceiling and on the joint guided surfaces of breakdown blocks along the axis of the breakdown pile (Fig. 7G).

In their shape and general appearance breakdown caves in gneiss very much resemble breakdown cham- bers in karst caves, suggesting that there is some mechanism for the removal of material from below.

\section{ROCK SHELTER-TUNNEL COMBINATIONS}

While most rock shelters are simple structures that do not penetrate far into the host rock, tunnels are developed into the rock mass at the back of some rock shelters. One example of this is Alavala Pothgul Lena, a large southfacing rock shelter. Towards its western side a small tube extends north into the rock mass from the back of shelter (Fig. 8A). An archaeological dig is located towards the western side of the shelter and to the south of the tube. Sediments exposed in this dig dip to the south, towards the open side of the shelter (Fig. 8B), suggesting that they may have been deposited by water flowing out from the tunnel. Similar rock shelter-tunnel combinations have been observed at Karannagoda Rajamaha Viharaya and Varana Rajamaha Viharaya.

\section{NITRE CAVES}

Davey (1821) listed twenty-two caves where niter occurred. From those he described it is clear that the Nitre Caves have a range of morphologies. Gebauer (2010) presented a new version of Davey's list, indicating on which topographic map sheet these caves were likely to occur. From his extensive literature study, Gebauer was only able to locate three of the twenty-two nitre caves listed by Davey on a map. In addition to the nitre caves listed by Davey the archaeological literature contains reference to niter at other locations, including Batadomba Lena (Kennedy \& Deraniyagala, 1989). Despite the lack of any apparent morphological similarity, the idea of nitre caves as a distinct group is so entrenched it seems useful to deal with them as a distinct group of caves.

Lunugala Lena (Vedi Lunu Galge, Nitre Cave, Nitro Cave, Meemora Cave, Doombera Cave, Doombera Granite Cave) is probably the best-documented cave in Sri Lanka that is not a recognised archaeological site. Gebauer (2010) devoted eight pages of his Cave Registry to the cave and lists twenty-two recorded variations of its name from the literature, summarised in parentheses above. It is also one of the few caves, which is not an archaeological site that was mapped prior to this project.

Nitre Cave (Lunugala Lena) is morphologically a tunnel cave, approximately $9 \mathrm{~m}$ wide at its entrance and extending for some $60 \mathrm{~m}$ southwards (Fig. 8C). Its entrance has an elliptical profile with a long axis sloping to the west. At Nitre Cave saccharoidal metamorphosed dolomite is interfoliated with granitic gneiss, with the lower part of the cave developed in gneiss and the upper part of the cave developed in granulite. Bedrock exposed on the western side of the cave entrance is significantly al- 

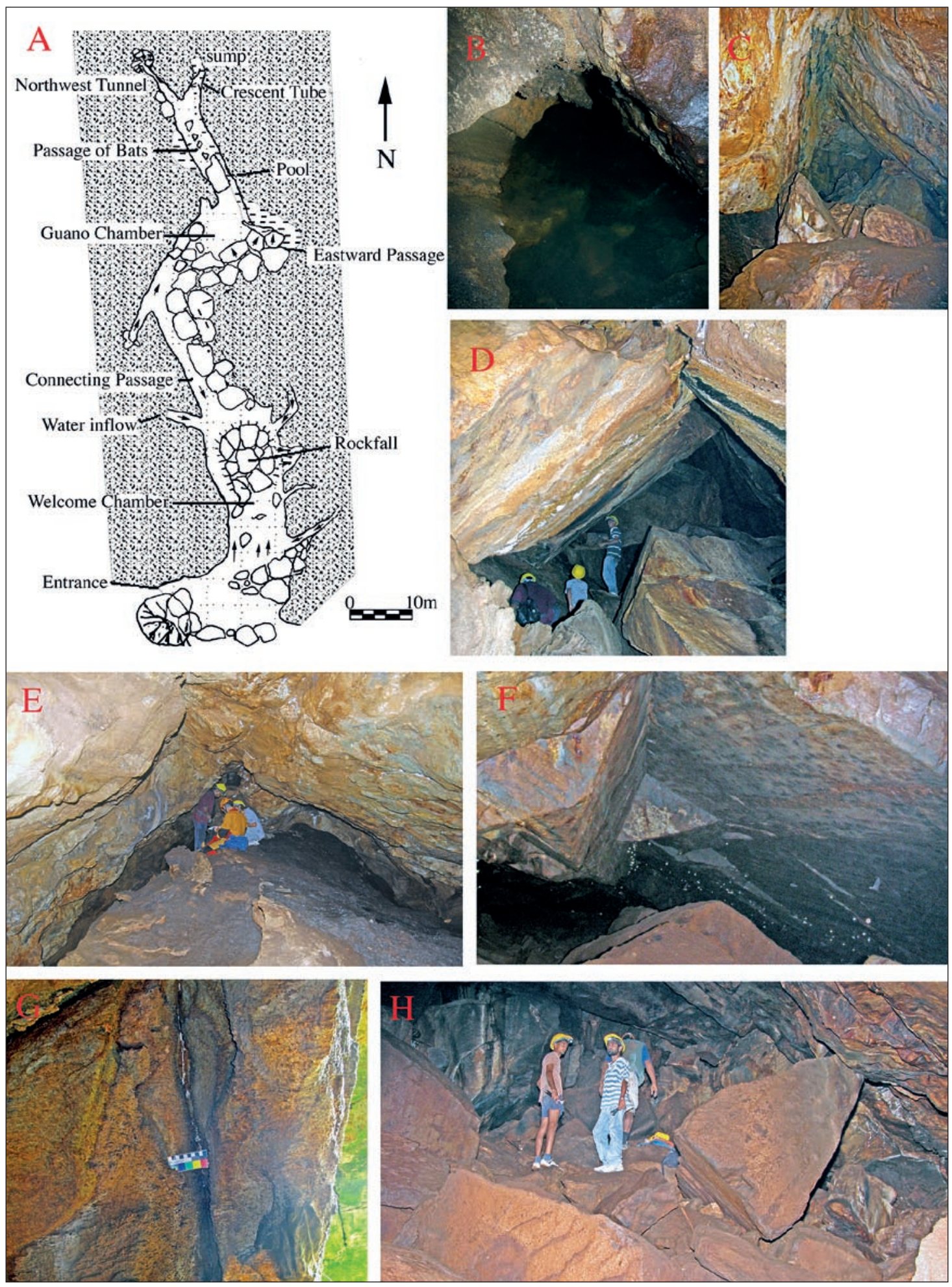

Fig. 7: Block Breakdown Caves

A, Map of Sthreepura Cave; B, Sump at NE end of Passage of Bats; C, Connecting Passage Sthreepura Cave, looking south showing breakdown along NNW-SSE striking joints; D, Guano Chamber Sthreepura Cave looking W showing breakdown along NE-SW striking joints; E, Passage of Bats, looking NNW showing axial breakdown pile; F, "A" Type ceiling due to failure along joints, main axis, Kosgala Vavul Lena; G, Half-tube in SE side of entrance, Kosgala Vavul Lena; H, Large breakdown blocks, Kosgala Vavul Lena. 


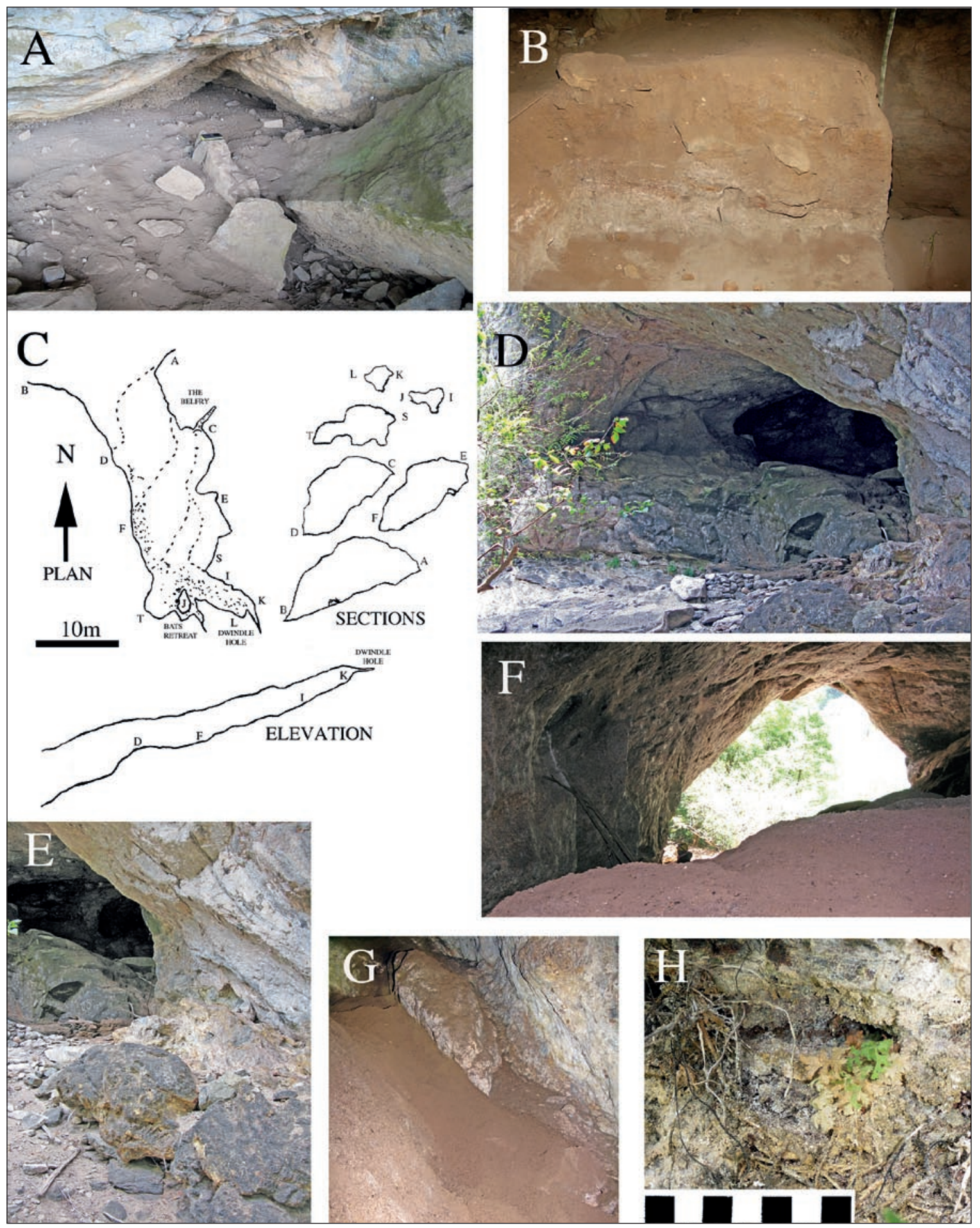

Fig. 8: Overhangs with Tunnels \& Nitre Caves

A, Entrance to small tube at rear of Alavala Pothgul Lena; B, Sediment exposed in archaeological excavation in Alavala Pothgul Lena. Bedding in sediment is dipping to the south away from the rear of the cave; $C$, Map of Nitre Cave modified after Peet (1946); D, Looking southeast at the entrance to Nitre Cave, note arch-like profile of entrance, elliptical inner profile and cliff rising to the left (eastern) side of entrance; $E$, Altered bedrock at western side of cave entrance near "B" in Fig. 8C; F, Looking out from Nitre Cave, note arch-like profile of entrance and guano-derived silt in foreground; $G$, Looking in along western side of Nitre Cave note narrow slot and deposit of loose guano-derived silt; H, Fern with bleached fronds and crystal deposits on vegetation on cliff at eastern side of entrance. Black squares on scale are $10 \mathrm{~mm}$. 
tered, apparently from its contact with the now-removed niter-bearing sediment.

A cliff forms the eastern side of the cave entrance. Ferns and other vegetation growing on this cliff have a bleached appearance apparently due to the high ionic strength of the seepage water to which they are exposed.
The cave floor is higher on the eastern side of the cave apparently due to the locally westerly dip of the foliation. A slot runs along the western wall. This area is filled with loose guano and dust. Two smaller tunnels extend to the east at the southern end of the cave; both are used by bats and have not yet been properly explored.

\section{SPELEOGENS}

A range of speleogens is found in the gneiss caves including pockets, tubes and half-tubes, cupolas, stepped ceilings and floors, selective solution forms and dolomite speleogens.

\section{POCKETS}

Circular and elliptical depressions with a diameter or long axis ranging between tens of millimetres and one metre occur in cave walls. In Alavala Tunnel Cave a series of elliptical pockets with a horizontal long axis of approximately $410 \mathrm{~mm}$, a short vertical axis of $200 \mathrm{~mm}$ and a depth of $130 \mathrm{~mm}$ are developed in a notch in the eastern wall of the cave ("iv" in Fig. 3A, Fig. 9A). Larger elliptical pockets, with a horizontal long axis of approximately $1 \mathrm{~m}$, a short axis of $600 \mathrm{~mm}$ and a depth of $200 \mathrm{~mm}$ are developed high in the wall of Batathota Cave (Fig. 9B). A pocket with a more complex form is located at the northern end of Batadomba Lena (Fig. 9D).

\section{TUBES AND HALF-TUBES}

As our study so far has concentrated on large open caves, little is known about the disposition of tube-like cavities deeper inside the rock mass. There is some evidence that these do exist from the exposure of a network of tubes in the base of the archaeological excavation in Fa-Hien Lena and from the exposure of half-tubes in the breakdown caves.

The openings of small tubes are found at the rear of the entrance chamber at Ravana Cave (Figs 9E \& 9G). The opening of a small complex tube, the Crescent Tube, occurs at the northern end of Sthreepura Cave (Fig. 9F).

Half-tubes occur in the ceilings of both arch caves and breakdown caves. A prominent, large half-tube runs roughly northeast to southwest across the ceiling of Batathota Cave (Fig. 9H). The origin of this feature is unclear.

In Kosgala Vavul Lena, half-tubes appear to be produced by breakdown along joints exposing tubes that originally ran along the joints as half tubes. Fig. 9I shows a right-angle junction of two tubes exposed by breakdown as two half-tubes.

\section{CUPOLAS}

Large cupola-like hollows have been observed in the ceilings of Batathota Cave, Batadomba Lena and Lunugala Lena but these have not yet been properly measured or photographed.

\section{STEPPED WALLS, CEILINGS AND FLOORS}

As a consequence of the spalling process, the surfaces of steep bedrock walls and ceilings in the caves are intersected by a series of steps frequently 20-40 mm high. A similar texture occurs in the bedrock floors of tubes. This can be observed in the floor of Alavala Tunnel Cave (Fig. 3E).

\section{SELECTIVE SOLUTION FORMS}

Localised areas of the rock surface exposed in caves show signs of being affected by selective solution of the gneiss. The two most common of these forms are quartz meshwork and prominent large crystals.

Quartz meshwork occurs where minerals other than quartz have been removed from the rock of the cave wall, apparently by solution, leaving behind an interconnected residual mesh or sponge of quartz. This wall surface is quite rough, due to the sharp edges of the quartz grains. Good examples of this form occur on the walls of Guano Chamber in Sthreepura Cave (Fig. 11F). It is likely that this process releases the mica plates found in the silt covering the floor of Sthreepura Cave.

Prominent large crystals are found in Lunugala Lena and Pelpola Lena. In Pelpola Lena selective solution appears to have removed small crystals, resulting in large crystals protruding from the cave ceiling (Fig. 9J).

\section{DOLOMITE SPELEOGENS}

While some speleogens develop across the boundary between the gneiss and irregular dolomitic bodies with the change in lithology having little effect on their form, some speleogens and surface forms appear to be restricted to dolomite. These include drip pits in Sthreepura Cave (Fig. 9K) and raindrop karren in saccharoidal metamorphosed dolomite near Lunugala Lena. 

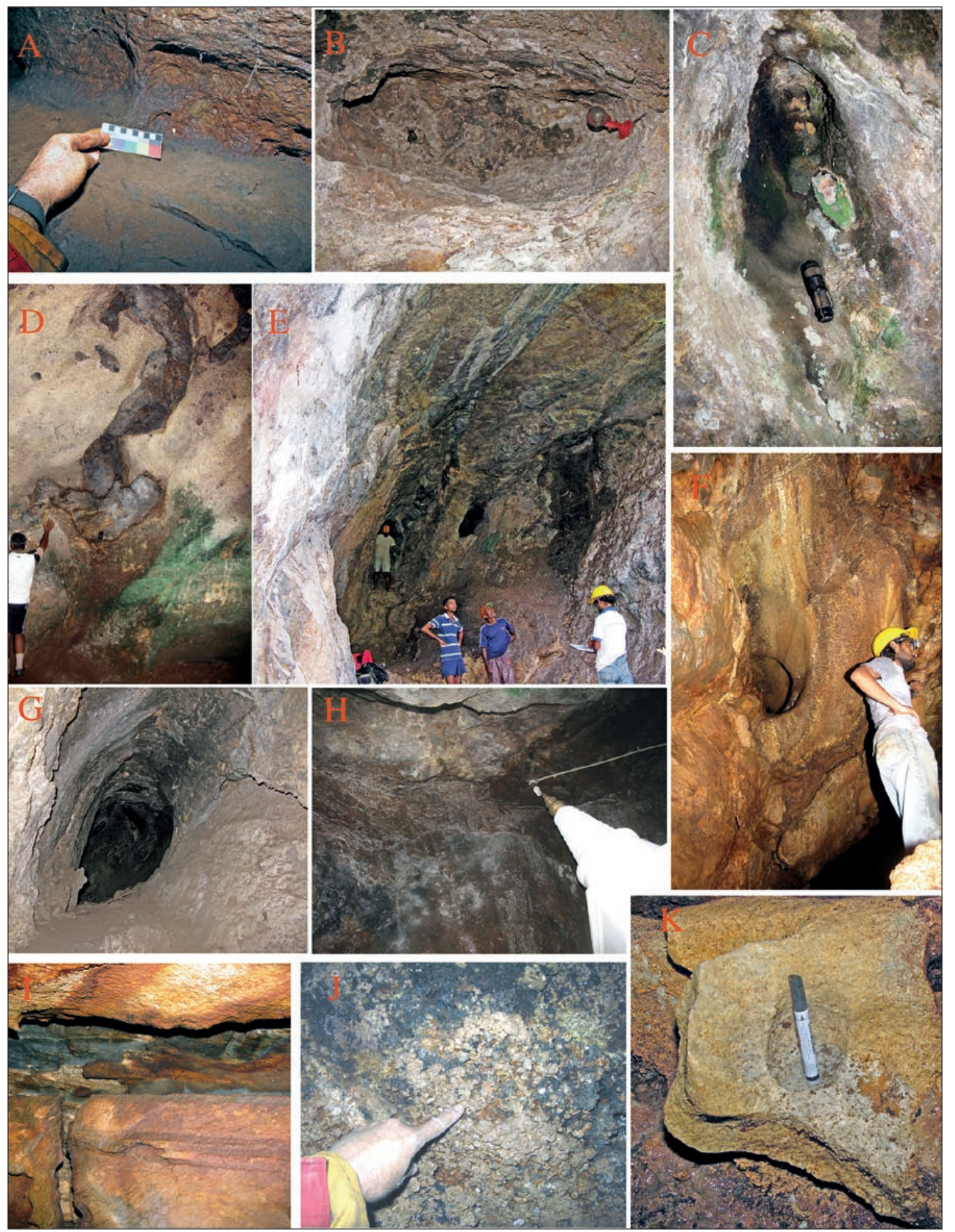

Fig. 9: Speleogens

A, Pocket developed in a wall notch, Alavala Tunnel Cave; B, High pocket behind monk statue, Batathota Cave; C, Pocket with vertical axis, south wall Batathota Cave; D, Centre pocket, Batadomba Lena; E, Elliptical tubes extending from the chamber of Ravana Cave; F, Crescent Tube, NE corner Passage of Bats, Sthreepura Cave; G, Vertical axis tube in Ravana Cave; H, Half tube above stupa, Batathota Cave; I, Joint tube junction with half-tube, Kosgala Vavul Lena; J, Large crystals protruding from etched cave ceiling, Treasure Hunters Chamber, Pelpola Lena; K, Drip pits in dolomite, Sthreepura Cave. 


\section{SEDIMENTS}

While entrance facies deposits in archaeological sites have been extensively studied often using advanced methods (e.g. Abeyratne et al., 1997) the focus has largely been on artefacts and bones. However this trend is changing with recent work by Jayasingha et al. (2009), Kourampas et al. $(2008,2009)$ and Perera et al. (2011) examining the artefacts, bones and host sediments in detail. Little is known about sediments formed deeper in the caves or of the relationship between the entrance facies and depositional systems in the caves.

The striking characteristic of the interior facies sediments in Sthreepura Cave is the apparent absence of clay. There the dominant sediment is organic silt, apparently derived from guano, with a significant quantity of mica fragments apparently derived from the bedrock. Neither clay nor quartz grains appear to be present. The most abundant sediment encountered in caves with a dark zone is recent guano. This is hardly surprising as colonies of microbats and sometimes also fruit bats are found in most of the large caves. Due to the previous focus on artefacts and bones in the entrance facies and the almost complete lack of knowledge about the interior facies, more work is required on the cave sediments.

\section{SPELEOTHEMS AND MINERALS}

Our examination of speleothems and cave minerals is in its infancy, but even at this stage some patterns are emerging. X-ray diffraction (XRD), undertaken in Australia, has been applied to only a few samples at this stage of the project. Bio-security considerations and aviation safety concerns meant that specimens with a biological component and specimens with suspect nitrates were not taken to Australia for analysis. Biological material was removed from all samples and all samples were soaked in alcohol and air-dried before packing in Sri Lanka. The samples were inspected on arrival at Sydney by Australian Quarantine Inspection Service staff.

XRD analysis was conducted at the Australian $\mathrm{Mu}-$ seum, Sydney using a PANalytical X'Pert Pro diffractometer with $45 \mathrm{kV}$ and $40 \mathrm{~mA}$ of $\mathrm{Cu}-\mathrm{k} \alpha$ radiation, employing $1^{0}$ divergence slit, $0.1^{0}$ receiving slit, $2^{0}$ antiscatter slit, with graphite monochromator and proportional counter. Scans were run at $1.2^{\circ}$ per minute from 7 to $70^{\circ}$ $2 \theta$ on powder samples reduced with an agate mortar \& pestle and prepared as an acetone slurry on a glass slide. Scans were interpreted using PANalytical X'Pert HighScore software.

\section{SILICA SPELEOTHEMS}

Opal, then called "hayalite", was first reported as a cave mineral in the form of "crusts" on "granite" by Davey (1821) in " a nitre cave in Doombera", that is Lunugala Lena (Hill \& Forti, 1997).

Small stubby stalactites are the most widespread form of silica speleothem in Sri Lanka. These are not restricted to caves, but have been found under boulders in streams and associated with the spalling process at the base of tors (Figs 10A, 10B \& 10C). These stalactites are not restricted to joints and other fractures, but are widely distributed over the ceilings of caves and under rocks, suggesting that they were deposited by seepage through the body of the rock.

Silica straws are less common but have been observed (Fig. 10D). Silica stalagmites and flowstones are not as common, but significant examples occur in Kosgala Vavul Lena (Fig. 10E). Though they resemble carbonate stalagmites and flowstones, the silica stalagmites and flowstones have a more rounded appearance, appear less crystalline and have much smaller micro gours than those typically seen in carbonate stalagmites and flowstones.

The abundance of silica speleothems in both caves and surface locations indicates that solution of silicates is an important active process in the vadose zone of gneissic and granitic rocks in Sri Lanka.

\section{PARTLY BIOGENIC SPELEOTHEMS}

A very strange deposit was observed on the wall of Eastward Passage in Sthreepura Cave (Fig. 10F). This deposit consists of a vertical strip of black material over which very light yellow crystal forms a thin crust down the centre of the strip. The black material is spongy and fleshlike to touch.

\section{FERRUGINOUS DEPOSITS}

Small ferruginous nodules occur on the ceiling of Sthreepura Cave (Fig. 10G). Irregular ferruginous staining is very common in the caves and as the images show, wall surfaces in caves with dark zones have a distinctive rusty hue. This is most likely due to the weathering of ferromagnesian minerals, such as biotite and hornblende. 

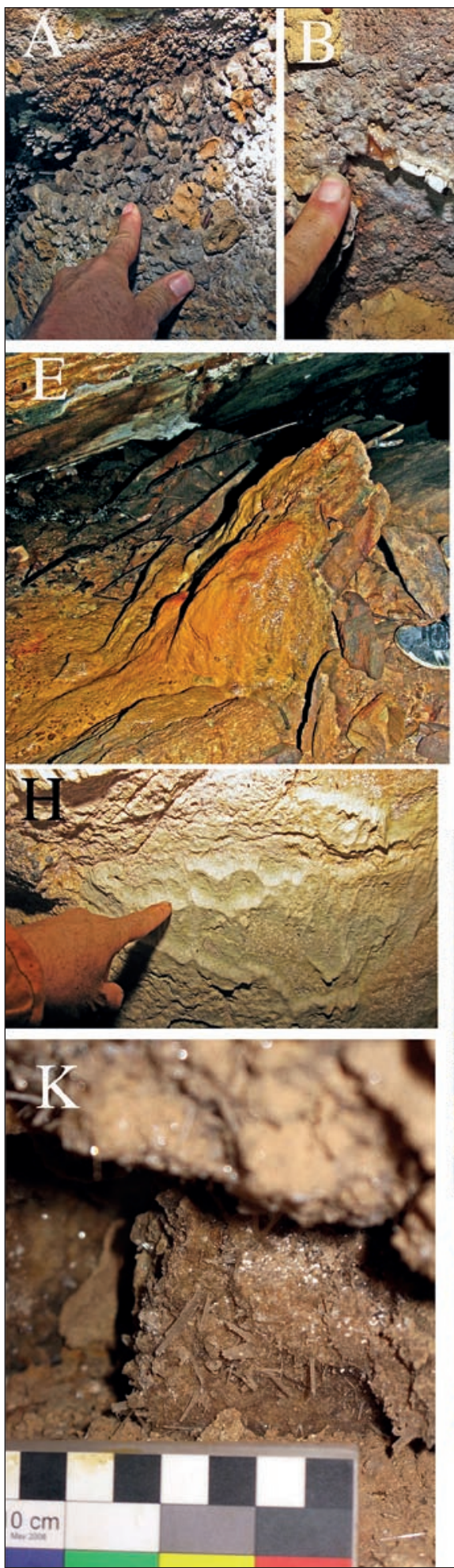
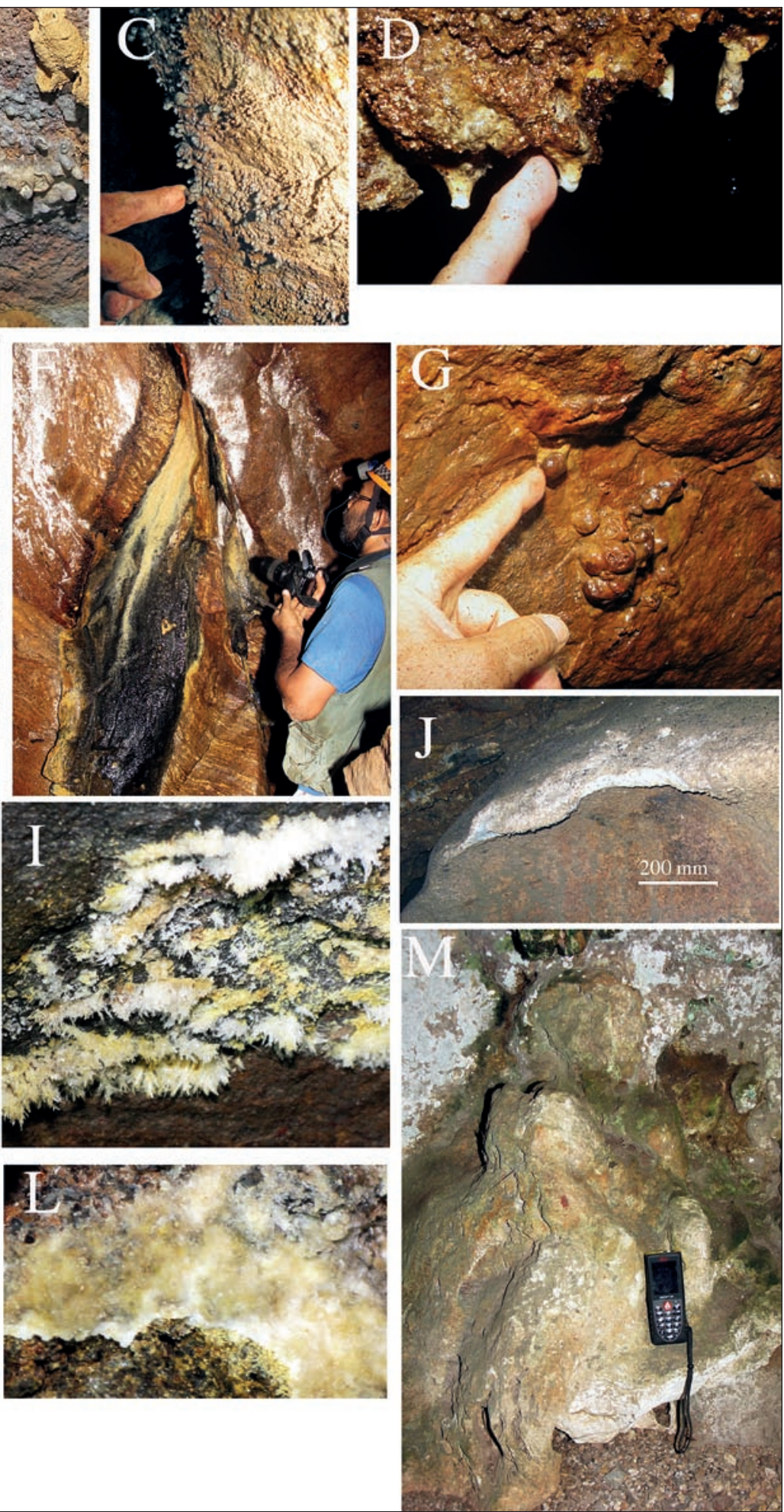

Fig. 10: Speleothems \& Minerals

A, Silica stalactites, Karannagoda Rajamaha Viharaya; B, Silica shawl, Karannagoda Rajamaha Viharaya; C, Nodular silica, Sthreepura Cave; D, Silica straws, Sthreepura Cave; E, Silica stalagmite \& flowstone, Kosgala Vavul Lena; F, Bizarre shawl, Sthreepura Cave; G, Ferruginous nodules, Sthreepura Cave; H, Moonmilk, Sthreepura Cave; I, Brushite crystals, Batadomba Lena; J, Coating on dolomite, Pelpola Lena; K, Gypsum crystals in bottom of excavation, Fa-Hien Lena; L, Gypsum crust, Batadomba Lena; M, Possible carbonate stalagmite, Batadomba Lena. 


\section{PHOSPHATES}

Archaeologists, e.g. Perera et al. (2011) reported authigenic phosphates in cave sediments exposed in their digs and attributed the source of the phosphate to dissolution of bone and calcareous ash. Dahanayake \& Subasinghe (1989) described phosphates derived from primary apatite in the bedrock while Jayasingha et al. (2009) correlated phosphate concentration in rockshelter sediments with human habitation. The abundance of bats and fresh guano in the caves, however, makes guano from bats, with a contribution in some cases from birds, the most likely source of phosphate in minerals and sediments in Sri Lankan caves.

Siffre (1975) mentioned the presence of moonmilk forming a spiders' nest in Sthreepura Cave. A pasty, moonmilk-like deposit was sampled in August 2010 from the western wall of the Entrance Chamber of Sthreepura Cave (Fig. 10H). X-ray diffraction has indicated that it is most likely composed of hydroxylapatite.

Small white and yellowish acicular crystals (Fig. 10I) grow on the ceiling of Batadomba Lena. X-ray diffraction indicated that these were most likely composed of brushite with possibly some gypsum present.

In the main chamber of Pelpola Cave metamorphosed dolomite is covered by a thick white paste (Fig. 10J). This appears to be the product of guano interacting with the bedrock. However initial X-ray diffraction studies have failed to detect any obvious phosphate phases and further studies of this material are being undertaken.

\section{GYPSUM}

Gypsum has been found in a number of forms including rams horns, blades, crystals and coatings. Rams horns and small blades occur in voids among the altered bedrock at the base of the excavation in Fa-Hien Lena (Fig. 10K). X-ray diffraction confirmed these to be gypsum with minor quartz and possibly minor calcite. At Batadomba Lena, a yellow crystalline crust is developed on the cave ceiling (Fig. 10L). X-ray diffraction indicated that this crust was composed of gypsum.

The presence of gypsum in two large arch caves indicates that there is sufficient evaporation in the cave environment for gypsum crystals to form and that sources of both calcium and sulfur are available. Calcium is most likely derived from the dissolution of irregular dolomitic bodies in the gneiss, and/or the weathering of calcsilicates. There are two likely sources for the sulfur component of gypsum in Sri Lankan caves, pyrite in the bedrock and bat and/or bird guano. Stable isotope studies will be undertaken to test for the origin when more samples are available.

\section{NITER}

Davey (1821) described the occurrence of niter at a number of caves including Nitre Cave (Lungala Lena) and presented chemical analyses of the niter deposits. Despite general agreement at the time that the niter was derived from bat guano, Davey (1821) argued that it was not derived from the guano, but from an inorganic reaction between the rock and the atmosphere.

\section{APPARENT CARBONATE SPELEOTHEMS}

Apparent carbonate speleothems are found in many of the gneiss caves. One of the larger examples is the stalagmite in Batadomba Lena (Fig. 10M). The mineralogy of apparent carbonate speleothems and tufas has not yet been investigated at this stage of the project.

\section{BEDROCK AND BEDROCK/CAVE RELATIONSHIPS}

Two striking features of the entries in the Cave Registry of Gebauer (2010) are firstly that almost all caves in Sri Lanka that are not located in the Jaffna Peninsula are said to occur in: -

"Precambrian (COORAY 1967) to Cambrian (DOMRÖS 1976) calcareous granulite (LEITER 1948) or metamorphosed, crystalline and dolomitic limestone /marble (COORAY 1967: 97) of the Khondalite series"

or similar, and secondly the degree of disagreement between and apparent confusion among different reporters as to the nature of the bedrock in which the caves are developed. For instance, while Lungala Lena is said by Peet (1946) and most other commentators to be developed in "very fine crystalline limestone" one of the cave's alternate names is Doombera Granite Cave (Onac \& Forti, 2011). As noted above confusion about the bedrock at Lungala Lena is hardly surprising given that the cave is developed in both granitic gneiss and metamorphosed dolomite.

Previous workers (e.g. Kukla, 1958; Siffre, 1975) presented maps that appear to be attempts to locate large caves in southern and central Sri Lanka on or close to the squiggly lines showing Precambrian marble, dolomite and/or calcsilicates on low-resolution geological 
maps of the island. The literature gives the distinct impression that, even though metamorphic rocks of granitic composition surround them, large caves in Sri Lanka have formed in metamorphosed dolomite or marble, not granitic gneiss.

Gebauer (2010, p 34 note 163) commented on the issue of cave development in gneiss as follows: -

"Brooks (1995: 22) surprises with a theory according to which gneisses are a group of rock "that does not normally develop cave passage." Currently (2009.10.04)

I am aware of 115 caves in gneisses on the Indian Subcontinent alone. Concerning the island of Sri Lanka itself, it had been already DAVY (1821: 419 footnote) who had come across "gneiss containing so large a proportion of carbonat [sic!] of lime, that it effervesces with an acid.« In a broad sense, calcite-rich gneisses are marbles and it will be difficult to deny that marbles contain high quality caves."

Our observations suggest that while there are true karst caves developed in impure dolomite in Sri Lanka and while some gneiss may be rich in carbonate, the caves we have described as gneiss and granite caves here are primarily developed in silicic rock. One of the important tasks for the future is to identify and document the caves in Sri Lanka that were formed by karst processes in large discrete bodies of carbonate rock within the Precambrian sequence.

The confusion about the lithology appears to have three origins: - i The idea that large caves should occur in carbonates

ii The similarity of some gneiss caves to karst caves

iii The association of gneiss caves with folia ("beds") and irregular bodies of metamorphosed dolomite within the gneiss.

While the first two origins relate largely to the experience and bias of both cavers and scientists whose primary reference point is karst caves in limestone, the third is a real feature of the geological environment.

Many gneiss caves in Sri Lanka intersect or are associated with layers or irregular, often dyke-like, bodies of carbonate rock. Sthreepura Cave, Kosgala Vavul Lena and Lunugala Lena appear to be underlain by layers of metamorphosed dolomite, while Batadomba Lena, Liyankabale Ela Twin Caves and Oil Lamp Cave intersect irregular and dyke-like bodies of carbonate rock.

In none of these cases is carbonate rock the principal material forming the walls or ceiling of the cave and most of the volume of the caves, with one exception, appears to have been produced by the removal (by solution or some other mechanism) or breakdown of siliceous rock.

The exception to the situation described above is Oil Lamp Cave, which has developed by the partial removal of an irregular dyke-like body of dolomite, "intruding" the country rock of granitic gneiss (Fig. 11A). The walls of the cave are largely composed of the surrounding granitic gneiss and the cave comes to a complete stop after approximately $2 \mathrm{~m}$ where it is completely blocked by dolomite (Figs 11B \& 11C).

\section{PROCESSES}

\section{SPALLING AND BREAKDOWN}

Spalling and exfoliation have been observed both in caves and on surface outcrops. Spalling from cave walls and ceilings appears to be the principal process actively expanding the volume of caves in gneiss. Fig. 11D shows active spalling from the ceiling of a tunnel cave at Karannagoda Rajamaha Viharaya while Fig. 11E shows spalling resulting from wedging due to the growth of silica in the sloping wall of Sthreepura Cave.

While spalling is largely confined to cave walls and ceilings a plate of rock can be seen partly separating from the floor in Alavala Tunnel Cave (Fig. 3E), suggesting that heaving also occurs in these caves.

\section{FELDSPAR SOLUTION}

The development of rocky relief such as quartz meshwork and prominent large crystals along with the lack of obvious clay in the cave sediments, suggest that rather than undergoing conventional weathering producing clays, feldspars in the gneiss are being removed by solution (Fig. 11F).

\section{REMOVAL OF PHANTOM ROCK}

Zones of phantom rock (Häuselmann \& Tognini, 2005), that is rock which has been weakened by the removal or alteration of the matrix or cement (ghost-rocks of Vergari \& Quinif, 1997; Quinif, 2011), have been observed at Kukuluwa Kanda Rajamaha Viharaya, Karannagoda 

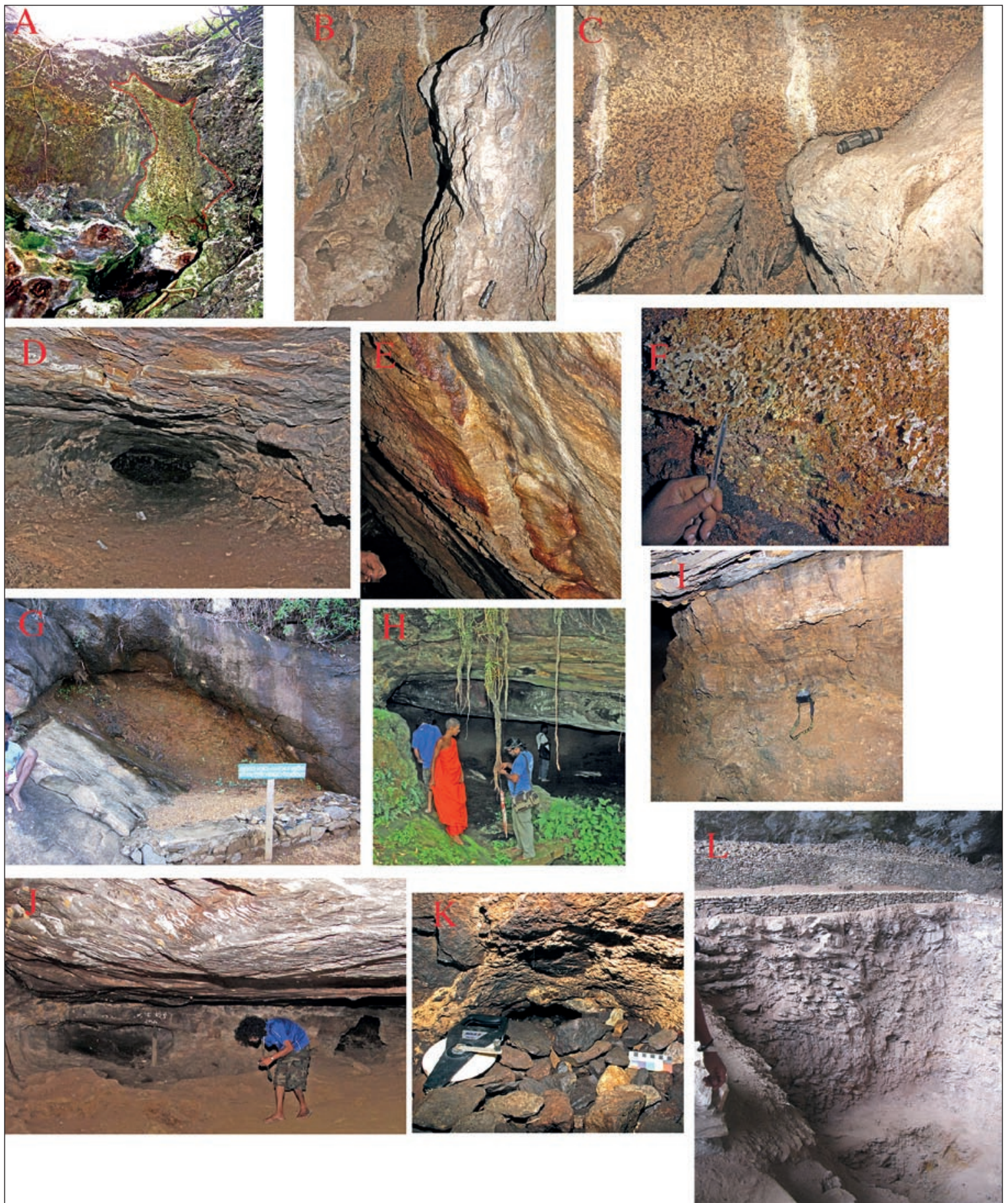

Fig. 11: Bedrock Relationships and Processes

A, Carbonate "dyke" above twin caves; B, Oil Lamp Cave looking towards end. White rock on sides is gneiss; speckled rock at end is dolomite with rusting ferromagnesian minerals; C, Termination of Oil Lamp Cave, note curved boundary between gneiss (white) and dolomite (speckled). Further removal of dolomite would extend the cave; $D$, Active spalling, in a tunnel cave at Karannagoda Rajamaha Viharaya; E, Wedging by silica growth resulting in exfoliation, Sthreepura Cave; F, Feldspar solution leaving meshwork of quartz, Sthreepura Cave; G, Phantom rock filling cave-shaped "cavity" in unaltered bedrock, Kukuluwa Kanda Rajamaha Viharaya; H, Looking in entrance of "foliation plane cave" Karannagoda Rajamaha Viharaya; I, Pillar of phantom rock, "foliation plane cave" Karannagoda Rajamaha Viharaya; J, Holes in remnant barrier of phantom rock, "foliation plane cave" Karannagoda Rajamaha Viharaya; K, Remnant of phantom rock on wall at end of Alavala Tunnel Cave; L, Excavation in Fa-Hien Lena exposing $6.3 \mathrm{~m}$ of altered bedrock. 
Rajamaha Viharaya and Alavala Tunnel Cave and a great mass of deeply weathered rock occurs below the cave floor at Fa-Hien Lena.

At Kukuluwa Kanda Rajamaha Viharaya a caveshaped zone of phantom rock occurs in the face of a bedrock terrace above the level of the main temple caves. This zone is partly eroded and can be seen to transmit seepage water (Fig. 11G). The guiding-joint seen on the left hand side of the image has produced a sloping elliptical profile similar to that seen in large tunnel caves such as Ravana Ella Cave.

The significance of the phantom rock feature at $\mathrm{Ku}-$ kuluwa Kanda Rajamaha Viharaya was underlined by a comment from the resident monk in June 2009, who said that he intended to dig out the site, i.e. remove the phantom rock, to make a new cave for a meditation centre. This suggests that phantom rock may be an important element in both the natural and artificial excavation of caves.

At Karannagoda Rajamaha Viharaya, cave temples and natural caves occur in gneiss high on the hillside at the base of a northwest to southeasterly trending cliff. At the northwestern end of the temple complex an expansive cave (approx. $21 \mathrm{~m} \mathrm{NW-SE} \mathrm{\&} 17 \mathrm{~m}$ NE-SW) with a planar ceiling dipping to the northeast is developed, apparently as a result of removal of a folium of phantom rock (Fig. 11H). Pillars of the phantom rock remain (Fig. 11I) and "windows" in sheets of remnant rock (Fig. 11J) suggest that prior to its almost complete removal a system of cave passages probably penetrated through the body of phantom rock. Towards the southeastern end of the temple complex, circular zones of phantom rock are exposed in the rockface.

Small remnants of phantom rock occur on the wall and ceiling at the far end of Alavala Tunnel Cave (Fig. 11K, "ii" \& "iii" in Fig. 3A). This, along with the observations at Kukuluwa Kanda Rajamaha Viharaya and Karannagoda Rajamaha Viharaya, raises the possibility that some tunnel caves originate from the natural removal of phantom rock and are then modified and expanded by spalling.

While the removal of phantom rock appears to be a vadose erosional process, commenced by seepage water and probably continued by small-scale fluvial processes, the mechanism and conditions under which the original phantomization took place has yet to be investigated.

At Fa-Hien Lena, archaeologists have excavated a large pit 6.3 metres deep in the floor of the arch cave, apparently thinking they were digging through sediment and/or accumulated spalls and breakdown from the cave walls and ceiling. Careful examination showed that this material was neither sediment nor breakdown but in-situ weathered/phantomized gneissic bedrock, with its foliation preserved (Fig. 11L). The bottom of the pit intersects a system of small cave tubes, just large enough for human entry. The material in the walls of the pit is quite porous, with signs that water has penetrated through the phantomized rock in specific zones. While some folia in the original gneiss have been removed or reduced to fines, others have remained resistant to the weathering process. The nature of the weathering process in the floor of Fa-Hien Lena requires further investigation.

\section{REMOVAL OF CARBONATE}

Leiter (1948) proposed that there were "pockets of limestone" in the metamorphic sequence and that caves formed "wherever the limestone has been dissolved out of these pockets".

Some small caves, like Oil Lamp Cave may have formed by this process, but by itself this cannot account for the development of large-scale caves in gneiss. Dissolution of underlying "beds" of carbonate rock is a possible, but not demonstrated, mechanism for the formation of large breakdown caves such as Sthreepura Cave and Kosgala Vavul Lena.

\section{PHREATIC SOLUTION OF SILICATE ROCK}

Some of the speleogens developed in gneissic bedrock such as pockets, half-tubes and cupolas suggest that phreatic solution of silicate rock may have occurred, particularly in the early phases of cave development. It is difficult, however to be sure that these were produced by phreatic solution of the bedrock, as many speleogens usually attributed to phreatic solution can be a product of rock phantomization (Vergari \& Quinif, 1997).

\section{CONCLUSIONS}

Initial studies of Sri Lankan gneiss and granite caves show a surprising similarity between the gross morphology and speleogens of these caves with those of conventional karst caves developed in massive limestone. While car- bonate rocks are associated with some caves, it is highly unlikely that many of the caves are simply the voids left behind following the removal of carbonate rocks by solution. 
While breakdown and spalling are actively expanding the caves, these processes cannot account for the development of the initial cavities or for the development of speleogens that mimic those found in low-energy phreatic or hypogene systems. The identification of phantom rock at several localities suggests that rock phantomization followed by removal requires serious consideration as a mechanism for speleogenesis in this environment.

The development of silica speleothems indicates that solution of silica is currently underway, not only along joints, but also within the body of the rock itself. Given the abundance of bats in most caves, the role of phosphatic leachates in rock etching and solution also requires consideration.
All major gneiss caves investigated and known so far are located well above the watertable and while pools are present no caves have yet been found that contain significant permanent streams, so it is not known if speleogenesis in gneiss and granite caves is hydrologically significant today.

Further study of these caves is important for karst science as they hold a mirror to our understanding of processes in carbonate karst. They look very much like limestone caves, but they are not. Their materials and chemistry are different, but common cave materials such as phosphates, evaporites and even carbonate minerals are present. They occur in ancient landscapes in even more ancient rocks, but also must have a strong relationship to the present tropical climate.

\section{ACKNOWLEDGEMENTS}

The clergy and administration of several Buddhist temples (Kukuluwa Kanda Rajamaha Viharaya, Pilikuththuwa Rajamaha Viharaya, Karannagoda Rajamaha Viharaya and Divaguhawa Lena in Kuruvita) are thanked for their co-operation, assistance and for providing local knowledge.

Professor Nimal de Silva, former director of PGIAR, is thanked for his wise vision in initially supporting this project. The Director of PGIAR, Professor Jagath Weerasinghe, is thanked for supporting the project and for the provision of facilities at Colombo. Professor Prishantha Gunuawardana, Professor Gamini Adikari and Professor Raj Somadewa are also thanked for their contributions. Messieurs Dinesh Devinuwara, Duminda Alahakoon and Ms Nayomi Sayanara Prasannajith are thanked for their assistance with the fieldwork.

Associate Professor Osborne would particularly like to thank Dr Wasantha Weliange, Mrs Aruni Premathilake, Ayoma and Paya for accommodation, sustenance and assistance with logistics in Sri Lanka.

Specimens for analysis in Australia were exported from Sri Lanka with permission of the Chairman, Geological Survey and Mining Bureau, Sri Lanka.
Daniel Gebauer is thanked for making his digital data available, while Dr Philippe Audra, Professor Pavel Bosák and Dr David Lowe are thanked for their assistance with obtaining references. Ms Penney Osborne assisted by reading the drafts. Ross Pogson publishes with permission from the Trustees of the Australian Museum, Sydney.

\section{NOTES ON SPELLING}

Singhalese place names have been rendered here with a "v" rather than a "w". Where the Singhalese place includes a term meaning cave, such as "lena" or "gal-ge", the word cave has not been added.

The Commission on New Minerals, Nomenclature and Classification (CNMNC) of the International Mineralogical Association (IMA), recognises the spelling "niter" for the orthorhombic mineral form of potassium nitrate. Niter is used in the text, except where the English spelling "nitre" is part of a place name, is included in a direct quotation, or has historic significance. 


\section{REFERENCES}

Abeyratne, M., Spooner, N.A., Grün, R. \& Head, J., 1997: Multidating studies of Batadomba Cave, Sri Lanka. - Quaternary Science Reviews (Quaternary Geochronology), 16, 243-255.

Brooks, S. J., 1995: Caving in Sri Lanka. - Orpheus Caving Club Newsletter, 31, 5-6, 22.

Brooks, S.J. 1995: Ms 20, Quoted in Gebauer, H. D., 2010. Resources on the Speleology of Sri Lanka, http://www.speleologie.de/forschung/lk/general/resources/bhb_2010_lk.pdf, 36 .

Cooray, P.G., 1967: An Introduction to the geology of Ceylon. - Spolia Zeylanica, 31, 1, 1-27.

Cooray, P.G., 1994: The Precambrian of Sri Lanka: a historical review. - Precambrian Research, 66, 3-18.

Dahanayake, K. \& Subasinghe, S.M.D., 1989: Secondary phosphate mineralization in a karstic environment in central Sri Lanka. - Mineralum Deposita, 24, 169-175.

Davey, J., 1821: An account of the interior of Ceylon and of its inhabitants with travels in that island, London: Longman, Hurst, Rees, Orme \& Brown.

Domrös, M., 1976: Sri Lanka: Die Tropeninsel Ceylon. Wissenschaftliche Länderkun, 12, 298, 37.

Deraniyagala, P.E.P., 1965: Some present-day problems of cave research in Ceylon. - Studies in Speleology, 1, 2-3, 143-147.

Fernando, W.I.S. \& Iizumi, S., 2001: Rb-Sr whole rockmineral isochron ages of plutonic rocks from the Wanni Complex, Sri Lanka. - Gondwana Research, 4, 1, 113-120.

Gebauer, H. D., 2010: Resources on the Speleology of Sri Lanka.

http://www.speleologie.de/forschung/lk/general/resources/bhb_2010_lk.pdf

Gebauer, H. D., Mansfield, R.E., Chabert, C. \& Kusch, K., 1996: Speleological Bibliography of South Asia including the Himalayan regions, Kathmandu: Armchair Adventure Press.

Häuselmann, P. \& Tognini, P., 2005: Kaltbach Cave (Siebenhengste, Switzerland): Phantom of the Sandstone? Acta carsologica, 34, 2, 383-396.

Hill, C. \& Forti, P., 1997: Cave minerals of the world, second edition, Huntsville, USA: National Speleological Society, 463p.

Jayasingha, P., Bandara, R., Adikari, G. \& Thantilage, A., 2009: Geoarcheological approach of Varana Cave Complex; sediments from an excavation of Varana Rock Shelter No-5, Department of Archaeology, Sri Lanka: Sri Lanka Annual Archaeological Congress2009, 45-57.
Jayasingha, P., Weliange, W.S., Dandeniya, A.S. \& Elgiriya, P., 2010: A classification for Sri Lankan caves. - Department of Archaeology, Sri Lanka, Annual Archaeological Congress-2010, 07-09 July 2010, $181-190$.

Kennedy, K.A.R. \& Deraniyagala, S.U., 1989: Fossil remains of 28,000-year-old hominids from Sri Lanka. - Current Anthropology, 30, 3, 394-399.

Kourampas, N., Simpson, I.A., Perera H.N. \& Deraniyagala, S.U., 2008: Late Pleistocene hunter-gatherers in the South Asian rainforest: geoarchaeology of inhabited rockshelters in south-western Sri Lanka. - Antiquity, 82, 316,

Kourampas, N., Simpson, I.A., Perera, N., Deraniyagala, S.U. \& Wijeyapala, W.H., 2009: Rockshelter sedimentation in a dynamic tropical landscape: Late Pleistocene-Early Holocene archaeological deposits in Kitulgala Beli-lena, Southwestern Sri Lanka. - Geoarchaeology: An International Journal, 24, 6, $677-714$.

Kukla, J., 1958: Jeskyne na Ceylone. - Ceskoslovensky Kras, 11, 165-169.

Laksiri, K., Gunathilake, J. \& Iwao, Y., 2005: Case study of the Samanalawewa Reservoir on the Walawe River in an area of karst in Sri Lanka. - Conference Proceedings Sinkholes and the Engineering and Environmental Impacts of Karst (GSP 144), Proceedings of Tenth Multidisciplinary Conference, doi: 10.1061/40796(177) 27

Leiter, N., 1948: Geographical study of the Nitre Cave district. - Bulletin of the Ceylon Geographical Society, 3, $3-4,61-72$.

Mathavan, V., Prame, W.K.B.N. \& Cooray, P.G., 1999: Geology of the high-grade Proterozoic terrains of Sri Lanka and the assembly of Gondwana: an update on recent developments. - Gondwana Research, 2, 2, 237-250.

Mathavan, V, Kalubandara, S.T. \& Fernando, G.W.A.R., 2000: Occurrences of two types of gem deposits in the Okkampitya gem field, Sri Lanka. - Journal of Gemmology, 27,1, 65-72.

Onac, B.P., \& Forti, P., 2011: State of the art and challenges in cave minerals studies. - Studia UBB Geologia, $56,1,33-42$.

Peet, G. A., 1945: Nitre Cave, Ceylon: An innovatory national park. - British Caver, 13, 69-71.

Peet, G, A., 1946: The Nitre Cave expedition. - British Caver, 14, 90-95. 
Perera, N., Kourampas, N., Simpson, I.A., Deraniyagala, S.U., Bulbeck, D., Kamminga, J., Jude Perera J., Fuller, D.Q., Szabó, K. \& Oliveira, N.V., 2011: People of the ancient rainforest: Late Pleistocene foragers at the Batadomba-lena rockshelter, Sri Lanka. - Journal of Human Evolution, 61, 254-269.

Quinif, Y., 2011: Ghost-rock structures and the nature of Azé Caves. - Quaternaire, Hors-seÅLrie, (4) 7-14

Siffre, M., 1975: Dans les abîmes de la terre. Paris, Flammarion. 304 pp.
Slabe, T., \& Hong, L., 2009: Significant subsoil rock forms- In Ginés, A., Knez, M., Slabe, T., \& W. Dreybrodt, Eds -Karst Rock Features, Karren sculpturing, Ljubljana, Založba ZRC, 123-138.

Vergari, A. \& Quinif, Y., 1997: Les paléokarst du Hainaut (Belgique). - Geodinamica Acta, 10: 175-187.

Villholth, K.G. \& Rajasooriyar, L.D., 2010: Groundwater resources and management challenges in Sri Lanka-an overview. - Water Resource Management, 24,1489-1513 DOI 10.1007/s11269-009-9510-6. 